\title{
A Systematic Review of the Prevalence of Hepatitis B Among Blood Donors in Ghana and Nigeria
}

\author{
Gana ve Nijerya'da Bulunan Kan Donörlerindeki \\ Hepatit B Prevalansının Sistematik İncelemesi
}

Abdul-Ghaffar Donkor ${ }^{1}$, Namaitijiang Maimaiti ${ }^{1}$

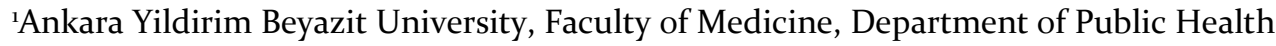

\begin{abstract}
Objectives: This study aims to compare the prevalence of hepatitis B among blood donors in Ghana and Nigeria through a systematic review.

Materials and Methods: A comparative-systematic review was conducted on the prevalence of hepatitis B among blood donors in Ghana and Nigeria. The articles reviewed were conducted including years from 2010 to 2017.

Results: The prevalence rate of hepatitis B among blood donors in Ghana ranged from 7.23\% to $14.60 \%$, while the prevalence rate among blood donors in Nigeria ranged from $7 \cdot 50 \%$ to $19.90 \%$.

Conclusion: Therefore, the prevalence rate of hepatitis B among blood donors in Nigeria is higher than the prevalence rate of hepatitis B among blood donors in Ghana though both countries are still considered hepatitis B endemic countries.

Key words: Hepatitis B, prevalence, blood donors, Ghana, Nigeria, comparative
\end{abstract}

Öz

Amaç: Bu çalışmada, Gana ve Nijerya'da bulunan kan bağışçıları arasındaki hepatit B prevalansının sistematik bir derleme ile karşılaștırılması amaçlamıștır.

Materyal ve Metot: Gana ve Nijerya'da kan donörleri arasında hepatit B prevalansı üzerinde karșılaștırmalı sistematik bir derleme yapıldı. İncelenen makaleler 2010 ve 2017 yılları arasında yapılmıștır.

Bulgular: Gana'daki kan donörleri arasında hepatit B'nin prevalansı \%7,23 ile \%14,6o arasındayken, Nijerya'daki kan donörleri arasında yaygınlık oranı \%7,50 ile \%19,90 arasındadır.

Sonuç: Her iki ülkede hepatit B için endemik olmakla birlikte, Nijerya'daki kan donörleri arasında hepatit B'nin yaygınlık oranı Gana'daki kan donörlerinden daha yüksektir.

Anahtar kelimeler: Hepatit B, prevalans, kan donörleri, Gana, Nijerya, karşılaştırmalı

Correspondence / Yazıșma Adresi:

Mr. Abdul-Ghaffar Donkor

Ankara Yildirim Beyazit University, Faculty of Medicine, Department of Public Health, o610o,

Bilkent / Ankara / Turkey

e-mail: abdulghaffardonkor@yahoo.com

Date of submission: 17.05 .2018

Date of admission: $15 \cdot 08.2018$

\section{Introduction}

Hepatitis B is a major global health problem. Globally, an estimated 257 million people are living with hepatitis B virus infection (defined as hepatitis B surface antigen positive). In 2015, hepatitis B resulted in 887,000 deaths, mostly from complications (including cirrhosis and hepatocellular carcinoma). Hepatitis B prevalence is highest in the the World Health Organization (WHO) Western Pacific Region and the WHO African Region, respectively $6.2 \%$ and $6.1 \%$ of the adult population are infected. In the WHO 
Eastern Mediterranean Region, the WHO South-East Asia Region and the WHO European Region, an estimated 3.3\%, 2.0\% and 1.6\%\% of the general population is infected, respectively. $0.7 \%$ of the population of the WHO Region of America is infected. ${ }^{1}$

Hepatitis B is highly endemic in West Africa where Ghana and Nigeria are located with a prevalence of $8 \%$, the highest in the world. ${ }^{2}$ Sweitzer et al. put the prevalence of chronic hepatitis B virus infection in Ghana at $12.92 \%$ in estimating the global burden of hepatitis B in 2013. ${ }^{3}$ Some experts have also put the prevalence rate of HBV in Ghana to be around $10-15 \% .{ }^{4}$ According to WHO, the prevalence rate of hepatitis B in Nigeria is about $11.2 \% .5$ Also, a pooled prevalence of HBV in Nigeria from studies carried out between 2000 and 2013 is $13.6 \%{ }^{6}$

A vaccine against hepatitis B has been available since 1982 . The vaccine is $95 \%$ effective in preventing infection and the development of chronic disease and liver cancer due to hepatitis B. ${ }^{1}$ WHO recommended hepatitis B vaccine incorporation into the expanded program on immunization (EPI) for all countries, especially in Africa in $1991 .{ }^{7}$ Ghana introduced Hepatitis B vaccine as part of the expanded programme on immunization among children in 2002 while the vaccine was introduced in Nigeria in 2004 as part of the National Program on immunization. ${ }^{8,9}$ Both Ghana and Nigeria do not give the vaccine at birth, but at 6, 10 and 14 weeks, respectively. WHO recommends that all infants should receive their first dose of vaccine as soon as possible after birth, preferably within 24 hours. Delivery of hepatitis B vaccine within 24 hours of birth should be a performance indicator for all immunization programmes but Ghana, Nigeria and few other countries do not give it at birth but six weeks after birth. ${ }^{8,9}$ This might be one of the reasons why the prevalence rate of hepatitis B is highest in West Africa.

A comparative analysis on the prevalence of Hepatitis B among blood donors was made for Ghana and Nigeria. These two countries are both located in West Africa where Hepatitis B is highly endemic and has the highest prevalence in the world hence, the decision to systematically review articles for both countries. Also, the review was conducted among blood donors because attitude of people towards hepatitis B screening is low in African countries. This might be due to the relatively low knowledge in these countries. ${ }^{10,11}$ Because of this, most hepatitis B diagnosis are made usually among prospective blood donors hence, the decision was to conduct the analysis among blood donors. This review therefore aimed to compare the prevalence of hepatitis B among blood donors in Ghana and Nigeria through a systematic review.

\section{Materials and Methods}

A detailed review of published articles on hepatitis B was conducted. A systematic search was conducted in PubMed, ScienceDirect, Google Scholar and Africa Journals Online (AJOL) databases to retrieve studies published between 2010 and 2017, assessing the prevalence of HBV among blood donors in Ghana and Nigeria. The key words used were; 'Hepatitis B, prevalence, blood donors, Ghana, Nigeria'. The main limits used were 'Humans' and 'English'. 
Articles included were studies published in peer reviewed journals between 2010 and 2017 which reported prevalence of HBV among blood donors in Ghana and Nigeria.

The number of articles reviewed was 14 articles, 7 from Ghana and the other 7 from Nigeria.

\section{Results}

The list of the selected articles from Ghana and Nigeria on the prevalence of Hepatitis B among blood donors is presented in Table 1.

Table 1. List of the selected articles from Ghana and Nigeria

\begin{tabular}{|c|c|c|}
\hline No & Title of selected articles & $\begin{array}{c}\text { Year of } \\
\text { publication }\end{array}$ \\
\hline $\mathbf{1}$ & $\begin{array}{l}\text { The prevalence of hepatitis B virus E antigen among Ghanaian blood } \\
\text { donors. }{ }^{12}\end{array}$ & 2013 \\
\hline 2 & $\begin{array}{l}\text { The Burden and Trend of Blood-Borne Pathogens among Asymptomatic } \\
\text { Adult Population in Akwatia: A Retrospective Study at the St. Dominic } \\
\text { Hospital, Ghana. }{ }^{13}\end{array}$ & 2017 \\
\hline 3 & $\begin{array}{l}\text { HIV, Hbv, Hcv And Syphilis Infections Among Blood Donors in } \\
\text { Koforidua, Ghana. }{ }^{4}\end{array}$ & 2016 \\
\hline 4 & $\begin{array}{l}\text { Sero-Prevalence of Hepatitis B Virus Infection among Blood Donors: A } \\
\text { Retrospective Study in the Kintampo Municipal Hospital, Ghana. }{ }^{15}\end{array}$ & 2014 \\
\hline 5 & $\begin{array}{l}\text { Prevalence of hepatitis B virus infection among blood donors at the } \\
\text { Tamale Teaching Hospital, Ghana. }{ }^{16}\end{array}$ & 2012 \\
\hline 6 & $\begin{array}{l}\text { Hepatitis B and C Viral Infections Among Blood Donors from Rural } \\
\text { Ghana. }{ }^{17}\end{array}$ & 2011 \\
\hline 7 & $\begin{array}{l}\text { Risk factors associated with hepatitis B exposure and the reliability of five } \\
\text { rapid kits commonly used for screening blood donors in Ghana. }{ }^{18}\end{array}$ & 2014 \\
\hline No & Title of selected articles from Nigeria & $\begin{array}{c}\text { Year of } \\
\text { publication }\end{array}$ \\
\hline $\mathbf{1}$ & $\begin{array}{l}\text { HBsAg, anti-HCV, anti-HIV and VDRL in blood donors: Prevalence and } \\
\text { trends in the last three and a half years in a tertiary health care facility in } \\
\text { Ile-Ife, Nigeria. }{ }^{19}\end{array}$ & 2010 \\
\hline 2 & $\begin{array}{l}\text { A Survey on the Prevalence of Hepatitis B Virus and Predisposing Factors } \\
\text { among Blood Donors in Two General Hospitals in Jigawa State Nigeria. }{ }^{20}\end{array}$ & 2017 \\
\hline 3 & $\begin{array}{l}\text { Prevalence of HBsAg and HIV among blood donors in Osogbo, Osun } \\
\text { State, Nigeria.. }\end{array}$ & 2013 \\
\hline 4 & $\begin{array}{l}\text { Prevalence of transfusion-transmissible hepatitis B infection among blood } \\
\text { donors in Sokoto, North Western, Nigeria. }{ }^{22}\end{array}$ & 2014 \\
\hline 5 & $\begin{array}{l}\text { Occult hepatitis B viral infection among blood donors in South-Eastern } \\
\text { Nigeria. }{ }^{23}\end{array}$ & 2014 \\
\hline 6 & $\begin{array}{l}\text { Occult Hepatitis B Virus Infection in Nigerian Blood Donors and } \\
\text { Hepatitis B Virus Transmission Risks. }{ }^{24}\end{array}$ & 2015 \\
\hline 7 & $\begin{array}{l}\text { Sexual transmission of the hepatitis B virus among blood donors in a } \\
\text { tertiary hospital in Nigeria. }{ }^{25}\end{array}$ & 2010 \\
\hline
\end{tabular}


Table 1 above represents the list of selected articles on hepatitis B among blood donors in Ghana and Nigeria, respectively. The selected articles from Ghana were from 2011 to 2017 with majority of the articles published in 2014. Also, the selected articles from Nigeria were from 2010 to 2017 with two of the articles published in 2010.

Table 2 below shows the research setting, research design, age ranges of participants and sample size of the researches conducted on hepatitis B among blood donors. It also shows the prevalence of hepatitis B among blood donors in Ghana and Nigeria. Majority of the studies conducted were cross sectional studies with some of the studies having small sample sizes. Also, most of the studies were conducted in urban areas with very few studies conducted in rural areas.

Table 2. Summary of prevalence of hepatitis B among blood donors in Ghana and Nigeria

\begin{tabular}{|c|c|c|c|c|c|c|}
\hline Country & $\begin{array}{l}\text { Study } \\
\text { design }\end{array}$ & $\begin{array}{l}\text { Study } \\
\text { period }\end{array}$ & $\begin{array}{c}\text { Study } \\
\text { location }\end{array}$ & $\begin{array}{c}\text { Study } \\
\text { population }\end{array}$ & Age of sample & Prevalence \\
\hline \multicolumn{7}{|l|}{ Ghana } \\
\hline Kumasi $^{12}$ & $\begin{array}{c}\text { Cross } \\
\text { sectional }\end{array}$ & $\begin{array}{c}2012- \\
2013\end{array}$ & Urban & 150 & 16 to 59 years & $13 \cdot 30 \%$ \\
\hline Akwatia $^{13}$ & $\begin{array}{c}\text { Cross } \\
\text { sectional }\end{array}$ & $\begin{array}{l}2013^{-} \\
2016\end{array}$ & Rural & 11,436 & 17 to 56 years & $7.23 \%$ \\
\hline Koforidua $^{14}$ & $\begin{array}{c}\text { Cross } \\
\text { sectional }\end{array}$ & 2016 & Urban & 426 & 17 to 54 years & $13.20 \%$ \\
\hline Kintampo $^{15}$ & $\begin{array}{c}\text { Cross } \\
\text { sectional }\end{array}$ & $\begin{array}{l}2010- \\
2012\end{array}$ & Urban & 3402 & - & $9.60 \%$ \\
\hline Tamale $^{16}$ & $\begin{array}{c}\text { Cross } \\
\text { sectional }\end{array}$ & 2009 & Urban & $5878 \& 576$ & 11 to 69 years & $11.59 \%$ \& $10.79 \%$ \\
\hline $\begin{array}{l}\text { Asante } \\
\text { Akin }^{17}\end{array}$ & $\begin{array}{c}\text { Cross } \\
\text { sectional }\end{array}$ & $\begin{array}{c}2006- \\
2008 \\
\end{array}$ & Rural & 2773 & 17 to 60 years & $10.53 \%$ \\
\hline Techiman $^{18}$ & $\begin{array}{c}\text { Cross } \\
\text { sectional }\end{array}$ & $\begin{array}{c}2012- \\
2013\end{array}$ & Urban & 164 & 17 to 57 years & $14.60 \%$ \\
\hline \multicolumn{7}{|l|}{ Nigeria } \\
\hline Ile-Ife $^{19}$ & $\begin{array}{c}\text { Cross } \\
\text { sectional }\end{array}$ & $\begin{array}{c}2006- \\
2009\end{array}$ & Urban & 14,500 & - & $7 \cdot 50 \%$ \\
\hline $\begin{array}{l}\text { Jiwaga } \\
\text { state }^{20}\end{array}$ & $\begin{array}{c}\text { Cross } \\
\text { sectional }\end{array}$ & 2017 & Urban & 546 & - & $13.00 \% \& 9.80 \%$ \\
\hline Osogbo $^{21}$ & $\begin{array}{c}\text { Cross } \\
\text { sectional }\end{array}$ & 2013 & Urban & 624 & 18 to 65 years & $19.90 \%$ \\
\hline Sokoto $^{22}$ & $\begin{array}{c}\text { Case } \\
\text { study }\end{array}$ & 2014 & Urban & 150 & 18 to 65 years & $9 \cdot 30 \%$ \\
\hline Abakaliki²3 & $\begin{array}{c}\text { Cross } \\
\text { sectional }\end{array}$ & 2014 & Urban & 113 & 18 to 65 years & $11.50 \%$ \\
\hline $\begin{array}{l}\text { South- } \\
\text { western } \\
\text { Nigeria }^{24}\end{array}$ & $\begin{array}{c}\text { Cross } \\
\text { sectional }\end{array}$ & 2015 & Urban & 429 & - & $17.00 \%$ \\
\hline $\begin{array}{l}\text { Tertiary } \\
\text { hospital }^{25}\end{array}$ & $\begin{array}{c}\text { Cross } \\
\text { sectional }\end{array}$ & $\begin{array}{c}2008- \\
2009\end{array}$ & Urban & 234 & 18 to 56 years & $17.10 \%$ \\
\hline
\end{tabular}


Study participants from the studies ages ranged from 11 to 69years. The highest prevalence among blood donors in Ghana was $14.60 \%$ and the least prevalence of $7.23 \%$. In Nigeria, the highest prevalence rate was $19.90 \%$ and the least prevalence rate was $7.50 \%$.

\section{Discussion}

Various studies have been reviewed on the prevalence of hepatitis B among blood donors in different parts of Ghana. The prevalence of hepatitis B among blood donors vary from one place to another in Ghana. Tanko et al study in 2013 revealed that the prevalence of hepatitis B among blood donors in Kumasi was $13.30 \% .{ }^{12}$ Another study conducted in Akwatia by Sylvester et al in 2017 showed that the prevalence rate was $7.23 \% .{ }^{13}$ Similar other studies conducted in 2016, 2014, 2012 and 2011 revealed that the prevalence rates were $13.20 \%$ in Koforidua, $9.60 \%$ in Kintampo, $11.59 \%$ \& $10.79 \%$ in Tamale and $10.53 \%$ in Asante Akim, respectively. ${ }^{1-17}$ Also, a similar other study was conducted in 2014 in Techiman revealed that the prevalence rate was $14,60 \% .{ }^{18}$ From the articles reviewed in Ghana, the highest prevalence is $\mathbf{1 4 . 6 0 \%}$ in Techiman in the Brong Ahafo region of Ghana and Akwatia in Eastern region of Ghana having the least prevalence of $7.23 \%$. The results of these studies among the blood donors are similar to the studies conducted among the general population which some experts put the prevalence of the general population to be between 10 to $15 \% 4$ while Sweitzer et al (2013) put the prevalence of the general population to be $12.92 \% .{ }^{3}$ Researches have also been conducted on the prevalence of hepatitis B among blood donors in different parts of Nigeria. The prevalence of hepatitis B among blood donors vary in different parts of Nigeria. Salawu et al in 2010 conducted a study and it revealed that the prevalence rate of hepatitis B among blood donors in Ile Ife was $7.50 \% .{ }^{19}$ Another study conducted by Salisu et al in 2017 showed that the prevalence rate in Jiwaga state were $13 \%$ \& $9.80 \% .{ }^{20}$ Similar other studies conducted in 2013, 2014, 2014, 2015 and 2010 respectively revealed that the prevalence rates were $19.90 \%$ in Osogbo, $9.30 \%$ in Sokoto, $11.50 \%$ in Abakaliki, $17 \%$ in South-western Nigeria and $17.10 \%$ in a tertiary hospital. ${ }^{21-25}$ From the articles reviewed in Nigeria, the least prevalence of hepatitis B among blood donors is Ile-Ife with a prevalence rate of $7.50 \%$. Osogbo has the highest prevalence of hepatitis B among blood donors with a prevalence rate of $19.90 \%$.

The prevalence rate among the blood donors in Nigeria according the articles reviewed is higher than the prevalence rate of the general population. According to WHO, the prevalence rate of hepatitis B among the general population in Nigeria is about $11.20 \% .5$ Musa et al in 2015 also put the prevalence rate among the general population of Nigeria to be $13.60 \%{ }^{6}$ The prevalence rate among the blood donors may be higher due to the fact that many people do not go for hepatitis B screening. They may therefore be hepatitis B positive but will not know until they go for blood donation.

\section{Comparison of the prevalence of hepatitis B among blood donors in Ghana and Nigeria}

Both Ghana and Nigeria are located in West Africa where hepatitis B has the highest prevalence among the general population in the world. ${ }^{2}$ Various articles published between 2010 and 2017 reviewed in this current study were among blood donors. The 
prevalence rate of hepatitis B among blood donors in Ghana ranged from $7.23^{13}$ to $14.60 \%{ }^{18}$ while the prevalence rate among blood donors in Nigeria ranged from $7.50 \%{ }^{19}$ to $19.90 \%{ }^{21}$. This showed that the prevalence of hepatitis B among blood donors in Nigeria is higher than the prevalence of hepatitis B among blood donors in Ghana. Though the prevalence rate in Ghana seems to be better than Nigeria, these two countries' prevalence rates are still higher than the prevalence of the general population of West Africa which is $8 \%{ }^{2}$. From the articles reviewed, the prevalence rate of hepatitis $\mathrm{B}$ among blood donors in Nigeria is higher than the prevalence rate of hepatitis B among blood donors in Ghana, though both countries are still considered hepatitis B endemic countries.

There is therefore the need to improve the measures on the prevention of Hepatitis $B$ especially on vaccination at birth, since these two countries do not vaccinate against hepatitis B at birth, but rather at 6weeks. This will help reduce the burden of the disease in these counties and in West Africa. Also, most researches conducted were at urban areas with few studies in rural areas. In addition, some of these researches conducted had small sample size which might not well represent the study population. Subsequent studies should therefore use larger sample sizes and consider studies in rural areas, as well.

\section{References}

1. World Health Organization. http://www.who.int/en/news-room/factsheets/detail/hepatitis-b 2017. Accessed on $15^{\text {th }}$ April, 2018.

2. World Health Organization. http://www.who.Int/Topics/Hepatitis/En/. 2015. Accessed (20 ${ }^{\text {th }}$ March, 2018.)

3. Schweitzer A, Hor JJ, Mikolajczyk RT, Krause G, Ott JJ. Estimations of worldwide prevalence of chronic hepatitis B virus infection: a systematic review of data published between 1965 and 2013. Lancet 2015;386(No. 10003):1546-55.

4. Ghana Web. Ghana Rated High Risk for Hepatitis B and C. http://www.ghanaweb.com/GhanaHomePage/health/Ghana-rated-high-risk for- Hepatitis-B-C-280781, Accessed on 2oth March, 2018.

5. World Health Organization, Nigeria. http://www.afro.who.int/news/nigeria-employs-numerousstrategies-create-awareness-viral-hepatitis-nationwide, Accessed on $20^{\text {th }}$ March, 2018.

6. Musa BM, Bussell S, Borodo MM, Samaila AA, Femi OL. Prevalence of hepatitis B virus infection in Nigeria, 2000-2013: a systematic review and meta-analysis. Nig J Clinical Practice 2015;18;168-72.

7. Beutels P. Economic evaluations of hepatitis B immunization: A global review of recent studies (19942000). Health Econ 2001;10;751-74.

8. Ghana Health Service. Policy on Immunisation in Ghana; GHS, Ministry of Health: Accra, Ghana. https://www.ghanahealthservice.org/downloads/GHS\%202008\%20Annual\%2oReport\%20Rev\%2ofin\%2 o12-09-09.pdf, Accessed on 2oth March, 2018.

9. National Programme on Immunization and Partners. Five Years National Strategic Plan 2003-2007. Abuja, Nigeria: 2002 National Programme on Immunization.

10. Abolaji BA, Obehi E, Innocent U, Folasade AB, Olayemi OO. Knowledge of hepatitis B virus infection, access to screening and vaccination among pregnant women in Ibadan, Nigeria. Journal of Obstetrics and Gynaecology 2013;33:155-9.

11. Abdulai MA, Baiden F, Adjei G, Owusu-Agyei S. Low level of Hepatitis B knowledge and awareness among pregnant women in the Kintampo North Municipality: implications for effective disease control. Ghana medical journal 2016;50(3):157-62.

12. Tanko R., Mohamed M., Kwaku K, Elliot D. The prevalence of hepatitis B virus E antigen among Ghanaian blood donors. Pan African Medical Journal 2013;31;1-4. 
13. Sylvester YL, Mavis PD, Gameli KN, et al. The Burden and Trend of Blood-Borne Pathogens among Asymptomatic Adult Population in Akwatia: A Retrospective Study at the St. Dominic Hospital, Ghana. Journal of Tropical Medicine 2017;10;1-7.

14. Alomatu H. HIV, HBV, HCV and Syphilis Infections Among Blood Donors in Koforidua, Ghana. University of Ghana, College of Health Sciences School of Public Health, Thesis (MPHIL), Ghana; 2016.

15. Williams W, Patrick H, Samuel A. Sero-Prevalence of Hepatitis B Virus Infection among Blood Donors: A Retrospective Study in the Kintampo Municipal Hospital, Ghana. Open Journal of Medical Microbiology 2014;4;64-9.

16. Julius TD, Sylvanus K, Ireneous NS, Patrick NA, Juventus BZ, Kenneth S. Prevalence of hepatitis B virus infection among blood donors at the Tamale Teaching Hospital, Ghana. BMC Research Notes 2012;5;1-5.

17. Nkrumah B, Owusu M, Frempong HO, Averu P. Hepatitis B and C Viral Infections Among Blood Donors from Rural Ghana. Ghana Medical Journal 2011;45;97-100.

18. Mohamed M, Michael O, Theophilus BK, Tahiru A, Emmanuel A, Patrick WN. Risk factors associated with hepatitis B exposure and the reliability of five rapid kits commonly used for screening blood donors in Ghana. BMC Research Notes 2014;7;1-8.

19. Salawu L, Bolarinwa RA, Adegunloye AB, Muraina HA. HBsAg, anti-HCV, anti-HIV and VDRL in blood donors: Prevalence and trends in the last three and a half years in a tertiary health care facility in IleIfe, Nigeria. International Journal of Medicine and Medical Sciences 2010; 2; 335-41.

20. Salisu A, Muktar MD, Salisu AI, Abdulhadi Y, Umar MA. Survey on the Prevalence of Hepatitis B Virus and Predisposing Factors among Blood Donors in Two General Hospitals in Jigawa State Nigeria. International Journal of Health and Medical Sciences 2017;3;29-37.

21. Opaleye OO, Tijani BA, Zakariyahu TO,Taiwo SS. Prevalence of HBsAg and HIV among blood donors in Osogbo, Osun State, Nigeria. International Research Journal of Medicine and Medical Sciences 2013;1;68-71.

22. Okwesili A, Usman I. Abubakar W, et al. Prevalence of transfusion - transmissible hepatitis B infection among blood donors in Sokoto, North Western, Nigeria. Health Sciences Research 2014;1;113-8.

23. Emmanuel N, Chinenye M, Ifeoma E. Occult hepatitis B viral infection among blood donors in SouthEastern Nigeria. Occult hepatitis B infection in Nigeria 2014;5;223-8.

24. Opaleye OO, Hoang VT, Sy BT, et al. Occult Hepatitis B Virus Infection in Nigerian Blood Donors and Hepatitis B Virus Transmission Risks. Occult Hepatitis B Virus in Nigerian Blood Donors 2015;10;1-13.

25. Adekanle O, Ndububa DA, Ayodeji OO, Paul OB, Folorunso TA. Sexual transmission of the hepatitis B virus among blood donors in a tertiary hospital in Nigeria. Singapore Med J 2010;12;944-7. 